remaining Papilionoideae occupy almost six hundred more, of which almost a third is devoted exclusively to that monstrous genus Astragalus, believed to be the largest of all angiosperm genera, with nearly four hundred distinct, or not so distinct, species in the area of the flora. What is the mystery of Astragalus? What mechanism is responsible for this extravagant polymorphy? What Darwinian sophistry can explain the adaptive advantages and evolutionary significance of this morphological prodigality? A flora cannot be expected to answer such questions, but it does prompt us to ask them.

For the remainder, the legumes are fairly well behaved -.just sufficiently problematic to make them interesting, but providing such a wealth of floral, fruit and vegetative characters as to make comparison and discrimination relatively easy, even if this structural exuberance does impose difficulties where limited space is allowed for description.

The compilers of volume three have done their work proficiently, and the standards of the earlier volumes are fully maintained. As previously, the letterpress and illustrations are a delight to the reader.

\section{R. D. MeIKLe}

\section{ATOMIC COLLISIONS}

Introduction to the Theory of lon-Atom Collisions

By M. R. C. MeDowell and J. P. Coleman. Pp. ix +442 . (North-Holland: Amsterdam and London, 1970.) Hfl. 80; $\$ 22.50 ; 186 s$.

THE authors' intention is to meet the needs of students beginning postgraduate study in the theory of ion-atom collisions, and experimental physicists who wish to distinguish the assumptions behind the various theoretical treatments. Rather than an introduction they seem to have produced a review of the theoretical methods used to date. A novice to the field might find this book hard going because it seems to assume a certain amount of familiarity with the field, for example I could find no explanation of terms such as "backcoupling" and "quantum defect". The book is, however, a valuable addition to the literature on atomic collisions and contains some useful material not readily available elsewhere.

The first two chapters discuss the classical and semiclassical descriptions of elastic scattering. Topics discussed include rainbow scattering, the interaction potential between atomic systems and the inverse scattering problem. Chapter three describes the classical theory of inelastic and rearrangement processes, including binary encounter treatments of capture.

Chapter four, on the impact parameter method, is the longest and perhaps the most useful chapter in the book, because there seem to be few other comprehensive treatments of the subject. After a discussion of direct collisions, much of the chapter is devoted to a study of rearrangement processes, including those involving "curve crossing"; it concludes by discussing methods of taking into account the effect of the continuum states. The equivalence of the impact parameter and wave treatments is given in an appendix. It seems a pity that the derivation of the basic equations was not given in more detail. The chapter would have been improved by the addition of a discussion of the problem of calculating differential cross-sections.

Chapters five and six deal with formal quantum scattering theory, including Coulomb scattering, the Born series, and the Faddeev equations. The application to excitation, ionization and rearrangement processes is given in chapters seven and eight. A very useful section describes the calculation of Drisko on the second Born approximation for proton-hydrogen charge exchange.

A helpful feature of the book is that the page number of the reference is given at the foot of every right hand page. A. R. HOLT

\section{Short Nofices}

Readings in Educational Psychology: Learning and Teaching. Edited by E. Stones. Pp. $x+478$. (Methuen: London, June 1970.) $50 s$; paper $25 s$.

THE psychology of learning is one of the more fashionable subjects in colleges and departments of education. And if that is not sufficient reason to suppose that this book will reach a wide audience, then the impressive list of essays and authors that it contains should make it very much in demand. There are fifty-two contributions on topics ranging from the development of speech and learning to the reliability and validity of examinations. The essays, which have all been reprinted from various books and journals, have been brought together and edited in a very readable manner, and $\mathrm{Mr}$ Stones has resisted the temptation to go off into some of the more woolly regions of animal behaviour.

Scale Atoms. Secondary School Kit. 85 component parts. (Heinemann (Education): London, July 1970.) 65s.

THIs is probably the most attractive of the many chemistry model sets that are now available, although $65 \mathrm{~s}$ seems a lot to pay for seventeen carbon atoms, thirty hydrogens and twenty others $(\mathrm{O}, \mathrm{N}, \mathrm{S}$ and $\mathrm{Cl})$. The kit is too small to make anything much more elaborate than a quinine molecule, but then, possibly, not every school child wants to become a protein chemist. One feature is the supply of alternative forms of carbon with round and square bonding pegs, which mimic, respectively, the freedom of rotation around a single bond and the rigid structure of a double bond. Perhaps most important of all, the atoms are fun to play with.

Wollastonite. By R. W. Andrews. Pp. vi+ 114. (HMSO: London, 1970.) 13s.

Following Sillimanite and Nepheline-Syenite in the series of monographs on economic minerals, prepared by the Mineral Resources Division of the Institute of Geological Sciences, this small book describes the properties, geological occurrence, industrial uses, production and world resources of wollastonite, a naturally occurring calcium silicate known largely from the United States. It has had a very short life as an industrial mineral, having been exploited in large quantities only in the past 20 years, but it is now used in the ceramics industry, chiefly in the United States, where the mineral is said to improve the strength of the product and to reduce the firing times. According to Dr Andrews, world reserves of proved wollastonite-bearing raw material exceed 60 million tons, and with a world production of only about 50,000 tons at present, there would scem to be a wide open field for potential new uses of this mineral.

Mathematical Methods for Physicists. By G. Arfken. Second edition Pp. $x x+815$. (Academic Press: New York and London, May 1970.) 135s.

THE second edition of this highly readable volume is spruced up with some important new sections, bringing the 800 pages of text nearer to a complete mathematios companion for physicists. Among the new additions are some basic sections on group theory-how did those come to be omitted in the first place? - and more sophisticated treatments of complex variables and Green's functions. Examples abound in the text, dividing up the long chapters quite persuasively. There is also a generous allocation of physics to liven up the formalism. One charge is that there is nothing on statistics, which is unfortunate in a book that aspires to completeness. It may be felt that the book is altogether a little top heavy, including the derivations of too many complicated functions. The text might be better balanced and cheaper if the author had contained this material within more modest bounds. 